\title{
The treatment of rhinophyma with excision and full-thickness skin graft
}

\author{
Rinofimanın eksizyon ve tam kat deri grefti ile onarımı \\ Kerem Polat*, İsmail Önder Uysal, Canan Filiz Karakuş, Emine Elif Altuntaş, \\ Togay Müderris, Ersin Tuncer, Suphi Müderris
}

Department of Otolaryngology (K. Polat, MD, Assist. Prof. İ. Ö. Uysal, MD, C. F. Karakuş, MD, Assist. Prof. E. E. Altuntaş, MD, Prof. S. Müderris MD), Department of Pathology (Assist. Prof. E. Tuncer, MD), Cumhuriyet University School of Medicine, TR-58140 Sivas, Department of Otolaryngology (T. Müderris, MD), Ankara Training and Research Hospital, TR-06340 Ankara

\begin{abstract}
Rhinophyma is a rarely seen benign, chronic disease of nasal skin, characterized by nodular growing of sebaceous glands that affect the distal half of the nose and cause several functional and aesthetic problems. This uncommon disease is especially seen in Caucasian males between the ages of 45-60 and the incidence is 12 times higher in men than in women. There are different methods for treatment of rhinophyma, and surgical treatment is accepted as gold standard. In this study, we reported a case with rhinophyma that was followed and surgically treated with excision and full-thickness skin graft in Cumhuriyet Universty School of Medicine Hospital.
\end{abstract}

Keywords: Rhinophyma, surgical excision, full-thickness skin graft

\section{Özet}

Rinofima burun derisinin nadir görülen, benign, kronik bir hastalığıdır. Burun distal kısmında sebase glandların progresif nodüler hipertrofisiyle karakterize bir hastalıktır ve çeşitli estetik ve fonksiyonel sorunlara neden olmaktadır. Nadir görülen bu hastalık özellikle 45-60 yaş aralığındaki Kafkas ırkı erkeklerinde izlenmektedir ve insidansı erkeklerde bayanlara oranla 12 kat daha fazladır. Rinofima tedavisinde farklı metodlar uygulanmakta ve cerrahi tedavi altın standart olarak kabul edilmektedir. Bu çalışmada biz Cumhuriyet Üniversitesi Tıp Fakültesi Hastanesinde takip ve cerrahi olarak eksizyon ve tam kat deri grefti ile tedavi edilen bir olguyu bildirdik.

Anahtar sözcükler: Rinofima, cerrahi eksizyon, tam kat deri grefti

Geliş tarihi/Received: February 06, 2012; Kabul tarihi/Accepted: November 07, 2012

\section{*Corresponding author:}

Dr. Kerem Polat, Kulak Burun Boğaz Anabilim Dalı, Cumhuriyet Üniversitesi Tıp Fakültesi, TR58140 Sivas. E-mail: kerem.polat@yahoo.com.tr

\section{Introduction}

Rhinophyma is a rare and benign disease of nasal skin, affecting middle aged and elderly males. It is a disease characterized by the progressive nodular hypertrophy of sebaceous glands and soft tissues at the distal part of the nose [1]. The surface of the nasal skin becomes erythematous and telangiectatic, and the pores grow large [2]. Surgical treatment options in cases with rhinophyma are surgical excision, electrocautery, cryosurgery or laser ablation $[3,4]$. There are several disadvantages such as bleeding, postoperative pain, ineffective cosmetic results for each of these treatment options $[5,6]$.

In this study, the treatment results are presented for the patient who was performed fullthickness surgical excision by surgical scalpel and was reconstructed with full-thickness skin graft. 


\section{Case report}

Our case is a 76-year-old male patient who applied to our clinic with complaints of enlargement, itching and bleeding at the tip of his nose and nasal obstruction. There were complaints of thickening and coarsening on the nasal skin for about a year. There was not a family story about rhinophyma. The patient did not have a history for alcohol use, allergy or chronic disease, but he has been using a pack of cigarettes in a day for about 50 years. The other routine ear, nose and throat examination and laboratory findings were normal. When the patient was admitted to our clinic, his nasal skin was observed to be hypertrophic and its outer surface was appearing like a telangiectatic mass. Multiple sebaceous gland pores on the skin of the nose was prominent and when pressure was applied upon it, a seborrheic effluent was seen. Both prenasis were obstructed due to the mass effect, so the patient was suffering from the nasal congestion. Additionally, this situation poses a problem in terms of cosmetics for the patient (Figure 1a-b). For the purpose of rhinophyma excision and repair with primary graft, the patient was operated under general anesthesia. 1\% lidocaine and epinephrine 1:100000 were injected to the surgical field with the aim of keeping the bleeding minimal. Excision was made with a scalpel on the nasal cartilages for the purpose of protecting the pericondrium and nasal aesthetic units were carefully removed as blocks. The deeply infiltrating mass was removed by total excision and sent to the pathology and evaluated histopathologically (Figure 2-3). The pathology report of the patient came as demodex folliculitis showing sebaceous hyperplasia (rhinophyma).
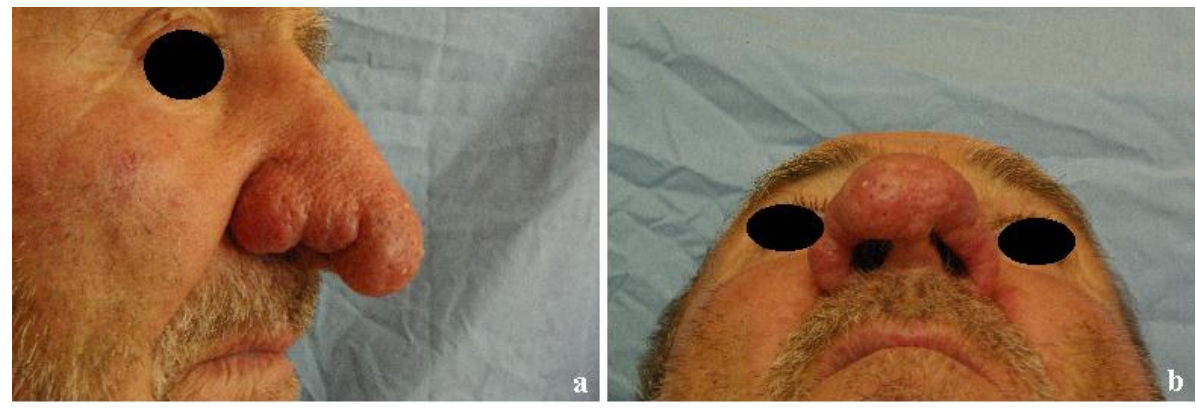

Figure 1a and $b$. Preoperative view of rhinophyma case that contains distal part of the nose, ala nasi and nasal tip and that narrows the nares.

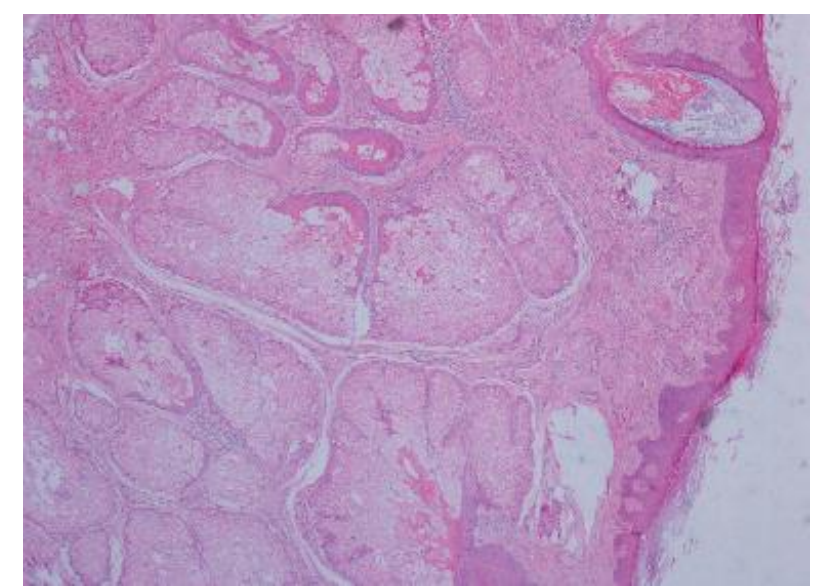

Figure 2. General view of the histopathology of rhinophyma; keratinized stratified squamous epithelium on surface, pilosebaceous units (40x; HE). 


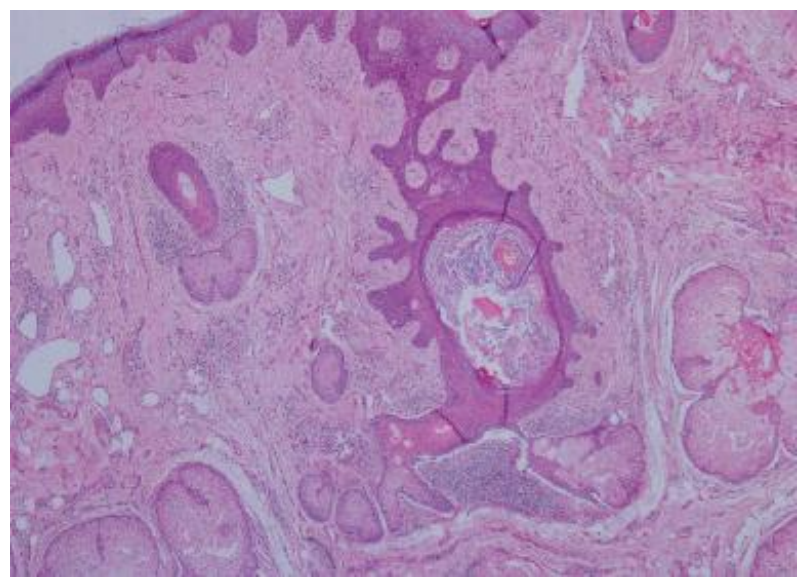

Figure 3. Endo-and peri-folliculitis having foreign body reaction around in deep dermis (100x; HE).

The defect occuring in the area of excision was repaired with a hairless full-thickness graft as a single piece that was taken from the right supraclavicular region. The skin graft was fixed to the defective nasal area with $4 / 0$ prolene suture and small incisions were made on the graft to prevent hematoma. As doing mesh with Terramycin, it was suturated in the form of bundle to make pressure on the graft. Afterwards, the defect in the shoulder was closed with $4 / 0$ prolene suture. Postoperative first day, medical dressing was changed and there was no graft loss or hematoma under the graft. In the postoperative period, the patient who did not experience any complications was discharged. In the next one year control period no problems occured, and the result was satisfying for both aesthetic and functional view (Figure $4 \mathrm{a}$ and $\mathrm{b}$ ).
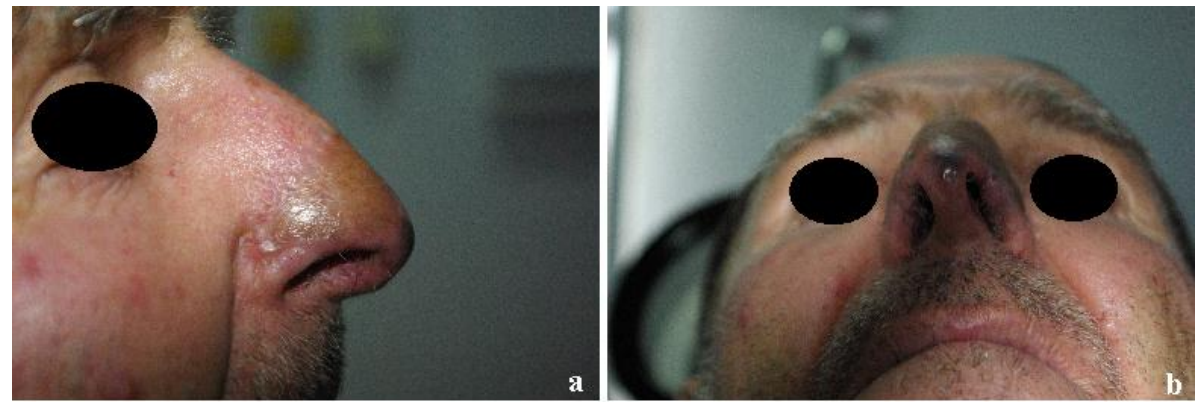

Figure 4a-b. Postoperative 4th month view of the patient treated with full-thickness excision of rhinophyma and reconstructed with a full-thickness supraclavicular skin graft.

\section{Discussion}

The rhinophyma term is derived from the words "rhis" which is a Greek term meaning "nose" and from "phyma" word that means "growing" and refers to the deformation according to the abnormal growing of nasal soft tissue [7]. Rhinophyma affecting the middle-old age group is a variant of rosacea [8]. It is also known as "potato nose" or "whiskey nose" in public [9]. This uncommon disease is especially seen in Caucasian males between the ages of 45-60 and the incidence is 12 times higher in men when it is compared to women [10-12]. Genetic factors, alcoholism, and increased steroid hormon levels are being accused in etiology but there is no proven relationship between them. In addition, microorganisms such as Demodex folliculorum were isolated in many cases, but their exact role in the etiology is not proven yet [1]. The only etiologic relation confirmed is the one with rosacea. Rhinophyma is a seldom chronic disease characterized by nodular growing of sebaceous glands that affect the distal half of the nose and cause several functional and aesthetic problems [13]. Other skin findings can be considered as 
erythema, telangiectasia and enlarged pore diameters. Further, tumor-like nodules can cause nasal obstruction and sleeping apnea. Bad smelling sebaceous discharge and superficial infection caused by debris accumulation in dilated acinar ducts are characteristic for rhinophyma. Rhinophyma is analyzed into two groups by histopathologically; the most common form is associated with acne rosacea. In this type, slowly improving but progressive hypertrophy and hyperplasia of sebaceous glands with fibrosis and telangiectasia is seen [14]. Additional to the inflammatory state, fibrovascular proliferation and epithelial acanthosis can be seen. As well as the hypertrophied glands, the ducts are dilated with sebum, keratotic debris and bacteria. Nasal cartilages are weakened. In a recent study, "transforming growth factor beta-2 (TGF- $\beta 2$ )" and the number of receptors were shown to be elevated in tissues with rhinophyma. This situation suggest that fibrogenesis is very important in pathogenesis of rhinophyma [15].

Rhinophyma must be separated from the malignant lesions, especially from basal cell carcinoma and squamous cell carcinoma. Although the malignant degeneration of rhinophyma is very rare, it should be kept in mind that it can be seen with these two malignancies with a rate of $15-30 \%$.

There are different treatment approaches of rhinophyma. Medical treatment does not give good results except the early period of phymatous changes. Topical metronidazole and systemic antibiotics are alternative treatment methods in patients with active inflammation. It is not certain that medical treatment methods can prevent development of rhinophyma or provide regression [13].

Surgical treatment is accepted as gold standard for rhinophyma [9]. There are many surgical approaches to rhinophyma:

1. Closing the defect with a flap or graft after total excision

2. Partial excision and secondary healing

3. Carbon dioxide (CO2), Neodymium-Yttrium-Aluminum-Garnet (Nd-YANG) and argon laser ablation

4. Cryosurgery

5. Electrosurgery.

There is not a common concept on which method should be preferred. Tetracycline and topical antibiotic treatment for 2 weeks before surgery help to reduce swelling and sclerosis [16].

Recently, argon laser, Neodymium-Yttrium-Aluminum-Garnet (Nd-YAG), ErbiumYttrium-Aluminum-Garnet (E-YAG) and carbon dioxide (CO2) laser using are recommended for the treatment of rhinophyma. $\mathrm{CO} 2$ laser have been reported for the first time for treatment of rhinophyma in 1980. It serves up excellent sensitivity, significant haemostatic effect, minimal complications and provides satisfying cosmetic results. It provides evaporation of water and loss of tissue by aiming intra-and extracellular water. Besides, provides an effective hemostasis at blood vessels with diameter up to $0.5 \mathrm{~mm}$ [13]. In the Hoasjoe and Stucker's study in which they treated the patients using CO2 laser, it has been noted that laser use is restricted because of the cost, safety conditions and requirement for special education to use laser [17]. Among the reported side effects of $\mathrm{CO}_{2}$ laser include erythema, hypopigmentation, hyperpigmentation, bleeding and fistula formation [18]. Furthermore, deep thermal damage can occur at adjacent normal tissues [4]. Argon laser affects only $0.5 \mathrm{~mm}$ depth of the tissue in each application. Therefore, argon laser can heal the telangiectasia, erythema and the surface. It is not practical for the treatment of a massive rhinophyma in the cause of over much repetition of the seances [19]. E-YAG laser is a new method performed at a wavelength of 2.940 $\mathrm{nm}$. It does minimal thermal damage with highly effective ablation of soft tissue. Thermal damage area is just a few microns deep [20]. There are some publications related to the combination of E-YAG and $\mathrm{CO}_{2}$ laser together [19].

Bogetti et al. [1] treated 7 patients with rhinophyma with different techniques. They used 
scalpel in 3, electrocautery in $2, \mathrm{CO}_{2}$ laser in 2 patients. They reported good results with all types of techniques and emphasized the advantages of excision with scalpel because it allows a sharp removal of the tissue and protects the underlying tissues for reepitelization and is cheap. They reported only one case with scar tissue because of the thermal injury who was treated with electrocautery. Rørdam et al. [9] treated 3 patients with electrosurgery and reported very good results.

In another study Lim et al. [8] used Carbon dioxide laser in 9 patients and obtained good results.

Redett et al. [19] reported 9 cases treated with different surgical techniques and the results were satisfactory only except in one case treated with electrocautery due to the scarring. Seven of them underwent partial-thickness excision, one underwent full-thickness excision and forehead flap reconstruction, and one had full-thickness excision with a fullthickness skin graft placement.

Intensive bleeding during the excision makes it hard to make accurate resection in hypervascularized tissue diseases such as rhinopyhma. For this reason, it is recommended to ensure a good control of hemostasis with a minimal thermal damage to the underlying sebaceous gland tissue, to allow spontaneous re-epithelialization with a quick and minimal scar tissue, and in order to minimize the risk of hypopigmentation; performing local dilute epinephrine injection and using bipolar cautery before the excision with a scalpel are also recommended [13-19]. Cauterization of the great vessels will take a long time, can give thermal damage to the underlying perikondrium and cartilage, and can also delay the healing, desiccate the cartilage and terminate with a likely deformity of the nose. Cauterization might be used for the hemostasis of small blood vessels [19]. Surgical reduction can be performed in two forms, either partial-thickness excision or full-thicness excision. In partial excision method the rhinophyma is shaved off tangentially and the residual deep pilosebaceous appendages produce re-epitelization $[1,19,21]$. At the time of surgical excision, particularly in patients with deep infiltrating advanced rhinophyma as in our case, with the presence of a neoplasm, complete layer excision of rhinophyma fibrous variant may be preferable and could be better to get more decent results in terms of cosmetics and recurrence. Following the full-thickness excision, it is recommended that the skin defect is closed with a full-thickness skin graft or flap. Grafts from auricula or nasal septum can be used in patients who underwent cartilage excision. Subtotal excision protects the underlying sebaceous glandular tissue and allows spontaneously reepithelialization. Complete recovery is provided within two or three weeks [22-25]. Spontaneous re-epithelialization after subtotal excision requires an uncomplicated surgery but carries a risk of recurrence [13].

\section{Results}

Rhinophyma is caused by the benign hypertrophy of sebaceous glands in the skin of the nose.It not only precludes the function of the nose, but also causes a cosmetic deformity. We performed a reconstruction procedure with a full layer of scalpel excision and fullthickness skin graft and achieved a normal skin cover that is compatible with the skin around the face in an advanced rhinophyma case which expanded the whole nose. Functional and cosmetic results were satisfying. We wanted to share our case in the literature to give an idea about the guide followed in the treatment of rhinophyma.

\section{References}

1. Bogetti P, Boltri M, Spagnoli G, Dolcet M. Surgical treatment of rhinophyma: a comparison of techniques. Aesthetic Plast Surg 2002; 26: 57-60.

2. Rohrich RJ, Griffin JR, Adams WP Jr. Rhinophyma: review and update. Plast Reconstr Surg 2002; 110: 860-69.

3. Fincher EF, Gladstone HB. Use of a dual-mode erbium: YAG laser for the surgical correction of rhinophyma. Arch Facial Plast Surg 2004; 6: 267-71. 
4. Goon PK, Dalal M, Peart FC. The gold standard for decortication of rhinophyma: combined erbium-YAG/CO2 laser. Aesthetic Plast Surg 2004; 28: 456-60.

5. Hsu CK, Lee JY, Wong TW. Good cosmesis of a large rhinophyma after carbon dioxide laser treatment. J Dermatol 2006; 33: 227-9.

6. Simo R, Sharma VL. Treatment of rhinophyma with carbon dioxide laser. J. Laryngol Otol 1996; 110: 841-6.

7. Fisher WJ. Rhinophyma: Its surgical treatment. Plast Reconstr Surg 1970; 45: 466-70.

8. Lim SW, Lim SW, Bekhor P. Rhinophyma: Carbon dioxide laser with computerized scanner is still an outstanding treatment. Australas J Dermatol 2009; 50: 289-93.

9. Rørdam OM, Guldbakke K. Rhinophyma: big problem, simple solution. Acta Derm Venereol 2011; 91: 188-9.

10. Har-El G, Shapshay SM, Bohigian RK, Krespi YP, Lucente FE. The treatment of rhinophyma. 'Cold' vs laser techniques. Arch Otolaryngol Head Neck Surg 1993; 119: 628-31.

11. Plenk HP. Rhinophyma, associated with carcinoma, treated successfully with radiation. Plast Reconstr Surg 1995; 95: 559-62.

12. Wiemer DR. Rhinophyma. Clin Plast Surg 1987; 14: 357-65.

13. Botero GES. Giant Rhinophyma: A Case Report. J Otolaryngol Head Neck Surg 1996; 24: 69-71.

14. Callé SC, Nickerson R, Evans JT. Rhinophyma. Otolaryngol Head Neck Surg 1994; 110: 253-4.

15. Pu LL, Smith PD, Payne WG, Kuhn MA, Wang X, Ko F, Robson MC. Overexpression of transforming growth factor beta-2 and its receptor in rhinophyma: an alternative mechanism of pathobiology. Ann Plast Surg 2000; 45: 515-9.

16. Odou BL, Odou ER. Rhinophyma. Am J Surg 1961; 102: 3-16.

17. Hoasjoe DK, Stucker FJ. Rhinophyma: Review of pathophysiology and treatment. J Otolaryngol 1995; 24: 51-6.

18. Karim Ali M, Streitmann MJ. Excision of rhinophyma with the carbon dioxide laser: a ten-year experience. Ann Otol Rhinol Laryngol 1997; 106: 952-5.

19. Redett RJ, Manson PN, Goldberg N, Girotto J, Spence RJ. Methods and results of rhinophyma treatment. Plast Reconstr Surg 2001; 107: 1115-23.

20. Orenstein A, Haik J, Tamir J, Winkler E, Frand J, Zilinsky I, Kaplan H. Treatment of rhinophyma with Er:YAG laser. Lasers Surg Med 2001; 29: 230-5.

21. Rex J, Ribera M, Bielsa I, Paradelo C, Ferrándiz C. Surgical management of rhinophyma: report of eight patients treated with electrosection. Dermatol Surg 2002; 28: 347-9.

22. Ersek RA, Denton DR. Rhinophyma: treatment with electrocautery and silverimpregnated porcine xenograft. Plast Reconstr Surg 1984; 74: 269-73.

23. Stucker FJ, Hoasjoe DK, Aarstad RF. Rhinophyma: a new approach to hemostasis. Ann Otol Rhinol Laryngol 1993; 102: 925-9.

24. Furukawa M, Kanetou K, Hamada T. Rhinophyma in Japan. Int J Dermatol 1994; 33: 35-7.

25. Riefkohl R, Georgiade GS, Barwick WJ, Georgiade NG. Rhinophyma: a thirtyfive-year experience. Aesthetic Plast Surg 1983; 7: 131-4. 